\title{
Analysis and Reflection on the overseas expansion of Chinese local hotels
}

\author{
XU Jinping \\ Department of Business Administration, Wuhan College, Wuhan 430069, China \\ xujinping@126.com
}

Keywords: Local hotel; Overseas investment

Abstract. Under the financial crisis after the current situation of global economic development, China's economic development and the reality of people's living standards is in gradual improve, tourism has gradually become the key driving force of the new normal economic transformation and upgrading. More and more people go abroad to see the outside world. To adapt to the trend and the needs of the development of enterprise itself, more and more enterprises cooperate with overseas hotels. The adjustment of travel and foreign investment policy make the behavior of the Chinese overseas hotel increase year by year, blowout phenomenon appear in 2016.

\section{Reasons for overseas Chinese hotel expansion}

Light assets operation. For traditional hotel, because the separation of light and heavy assets management trends are becoming ever more obvious, the hotel group with strength and capital hopes to through the brand output form to expand overseas.

Policy incentives. Positive policy is a big trigger to promote other areas overseas hotel industry a big source of investment subject. Insurance new released in August 2014 by the state council clearly put forward in the article "ten", to encourage the Chinese insurance companies try to form, "go out" through multiple channels. Business insurance it waldorf Astoria was directly encouraged by this policy. For real estate enterprises, overseas investment, the hotel can spread risk, can also set up offshore financing platform, and improve efficiency of capital turnover to alleviate the pressure of the money.

Transnational strategy .China's outbound tourism consumption is on the rise. According to data from 2015, 117 million people travel abroad; outbound tourism cost $\$ 155$ billion, up 20\% from a year earlier. As rigid demand for outbound tourism, accommodation natural contains the unlimited business opportunities. Global tourism will develop steadily and will continue to grow faster than the world economic growth. Tourism industry to maintain strong growth in the asia-pacific region, the global tourism center of gravity will accelerate the shift.

Asset value. Overseas investment in local hotels in the hospitality industry is mainly divided into two categories, one kind is the main business of tourism hotel, Shanghai jin jiang international, for example, its overseas expansion, the main business do big demand, "hopes China's overseas tourism development trend, become a global hotel"; Another kind is like business insurance and insurance of the sun's large investment institutions,

\section{Types of Chinese companies overseas expansion}

According to their own operating conditions, Chinese companies are divided into two tyoes, such as the resources conditions of different. Overseas investment also has different types. Chinese overseas hotel investment has the following eight categories: 
Table 1 Types of Chinese companies hotel overseas investment

\begin{tabular}{|c|c|c|}
\hline $\begin{array}{c}\text { Serial } \\
\text { number }\end{array}$ & Types & Typical cases \\
\hline 1 & $\begin{array}{l}\text { Hotel brand } \\
\text { output }\end{array}$ & $\begin{array}{l}\text { Case 1: in April 2013, kaiyuan tourism group with } 10.5 \text { million euros for the original } \\
\text { golden tulip hotel in Frankfurt, Germany, after comprehensive renovation for } \\
\text { Frankfurt kaiyuan hotel. }\end{array}$ \\
\hline 2 & $\begin{array}{l}\text { Buy hotel } \\
\text { property }\end{array}$ & $\begin{array}{l}\text { Case 2: in October 2014, } \$ 1.95 \text { billion deal to buy U.S. business insurance group waldorf } \\
\text { astoria hotel in New York. } \\
\text { Case 3: in December of } 2014 \text {, China's xing eed marriott hotel group's } \$ 165 \text { million } \\
\text { acquisition of Los Angeles international airport. }\end{array}$ \\
\hline 3 & $\begin{array}{l}\text { Investment } \\
\text { hotel } \\
\text { property }\end{array}$ & $\begin{array}{l}\text { Case 4: in July 2014, wanda to invest } \$ 900 \text { million in the United States to build a height } \\
\text { of } 350 \text { meters, the floor } 350 \text { Chicago layer including the five-star hotels and luxury } \\
\text { apartments and commercial projects. }\end{array}$ \\
\hline 4 & $\begin{array}{l}\text { Buy foreign } \\
\text { brands }\end{array}$ & $\begin{array}{l}\text { Case 5: in January } 2015,4 \text {, fosun group and its partners in the price of } 24.6 \text { euros per } \\
\text { share purchase } 960 \text { million euros worth of club med group co., LTD (fosun } \\
\text { international has a } 62.6 \% \text { stake, China uts travel accounts for } 8.7 \% \text { ). }\end{array}$ \\
\hline 5 & Swaps brand & $\begin{array}{l}\text { Case 6: on May 12, 2013, Greenland group of independent brand Frankfurt platinum le } \\
\text { hotel business formally, is with the Spanish MELIA (constant) hotel group of sharing } \\
\text { resources, swap market first right replacement project, green space, jinan, tianjin two } \\
\text { hotels will entrust MELIA authorized management. Greenland group on July } 4,2013 \text { and } \\
\text { has since hotel through equity transfer exchange, income, Barcelona, Madrid } 2 \text { hotels, a } \\
\text { total of } 1.5 \text { billion yuan, and the hotel will use platinum and platinum le brand, by the idea } \\
\text { of management. }\end{array}$ \\
\hline 6 & $\begin{array}{l}\text { Franchisdisin } \\
\mathrm{g}\end{array}$ & $\begin{array}{l}\text { Cases } 7 \text { franchising jinjiang star in September 2011, and the Philippines for jia } \\
\text { (international) formally signed, to the outside world in the form of brand output, through } \\
\text { the brand authorization to jinjiang star brand in the Philippines. } \\
\text { Case 8: jinjiang star in January 2014, the brand franchise agent in Indonesia right granted } \\
\text { to local products group. }\end{array}$ \\
\hline 7 & Accrediting & $\begin{array}{l}\text { Case 9: in November 2014, the east is hotel group anda hotel management co., LTD and } \\
\text { Singapore southeast Asia market cooperation agreement, the latter will get a hotel group } \\
\text { brand east city convenient hotel in Singapore and Malaysia market of sole agency, in } \\
\text { addition will also get are two Middle East yi cheng hotel brand with appropriate authority } \\
\text { is in southeast Asia. }\end{array}$ \\
\hline 8 & Joint venture & $\begin{array}{l}\text { Case 10:8 April 2011, camce cash investment in Laos a company, a joint venture set } \\
\text { up camce tourism development (Laos) co., LTD., joint development of } \$ 37 \text { million } \\
\text { worth of Laos post Bob state hotel projects. }\end{array}$ \\
\hline
\end{tabular}

By the example above, you can see that the investor can be divided into two categories, the hotel industry and the hotel industry enterprises. On the operation mode between asset light mode and heavy assets; According to the relationship between acquiring companies and target companies, has a horizontal m\&a, vertical m\&a, and mixed m\&a. This article will be to the Chinese citizen's outbound tourism as the target market of the overseas investment of Chinese hotel enterprises as object is discussed.

\section{Prospect analysis of China's domestic hotel overseas expansion}

Political. Country's attitude to Chinese overseas hotel can be analyzed from investment policy and policy two aspects to analyze tourist hotel industry.

(1) Foreign investment policy. In 2012, the eighteenth big proposed "to speed up the pace of go out, the enhancement enterprise international operation ability, foster a batch of world-class multinational companies". [1]In 2013, our country put forward the "area" initiative to provide strategic support of "going out", create a vast heaven and earth for foreign direct investment. In 2015, "the central committee of the communist party of China, the state council on establishing a new system of the open economy several opinions put forward to establish and implement the strategy of going out in the new period the state the principal position of foreign investment to establish enterprises and individuals, efforts to improve the quality of foreign investment and efficiency. 
(2) The tourism hotel industry policies. Since 2015, the country developed a series of policies to promote the development of tourism industry; tourism industry has become a national strategic industry. Tourism is a key driven force for the economic transformation and upgrading under the new normal, the key member of the national economy strategic position, "much starker choices-and graver consequences-in" into the national "much starker choices-and graver consequences-in" key national tourism development planning special planning.

Economic. (1) Per capita national income. The national bureau of statistics announced on January 19, 2015 economy, according to data of 2015 China's annual gross domestic product (GDP) of 67.67 trillion yuan, ranked second in the world, second only to America. Although China's GDP is far from can't keep up with the United States, but is very considerable. However, China's GDP per capita of $\$ 2015$ to $\$ 52000$ (in 1.3 billion) population, is about $\$ 8016$. Forecasts suggest that predicted China's per capita GDP is expected to surpass Japan in 2040.

(2) Currency

(3) Inflation

Social. Statistics according to the world tourism organization, international tourism growth hit a record high in 2015, the international tourism passengers rose $4.4 \%$, to 1.184 billion. Compared with the 50 million world traveled overnight visitors. International tourism people 6 years are in a row at a speed of more than $4 \%$ growth. International tourists travelling to Europe for more than 600 million people in the first place, a year-on-year increase of 29 million people. Visitors to the asia-pacific region are nearly 277 million person-times, a year-on-year increase of 13 million passengers. Visitors to the Americas are nearly 200 million person-times. China and the United States, Britain, followed by the 2015 international tourists top three largest source. Because the tourism products richness continues to increase, the price has a strong appeal, combined with the visa's bid to host the efficiency is improved, making mainland China in 2015 to about 3 million tourists, an increase of $16 \%$ over the previous year. [2] According to the forecast the U.S. department of commerce, the number of Chinese tourists or will rise by an average annual growth of $18 \%$, is expected to reach 4.9 million by 2019 . At that time, China will become the largest overseas tourism tourist market.

Technical. (1) Air. China's civil aviation passenger transport market since 2011 into the mature period, 2011-2015 forecast average growth rate of 9\%, against 14\% in 2004-2010. In 2015 China's civil aviation ticket sales for the first time more than 400 million copies, 405 million. The Chinese market is becoming the core of the global airline industry growth momentum. Data from the international aviation organization, by 2025 a third of world's passenger flights are expected to come from Asia. The civil aviation passenger transport has been completed by the transition of the high-end services to the public services, as the number of single flight from up to down; civil aviation passenger transport has become an important transportation and long-haul travel.

(2) Information technology. With the development of information technology and the popularization of the Internet and mobile terminals, supply side are increasingly using the Internet platform to provide real-time online query and booking international routes, destination information query, accommodation booking services, and transparent competitive prices, and the flight reservation is convenient and safe and reliable, also provides overseas returned halted ticket (ticket) outside the reservation.

\section{Risks and countermeasures of overseas Chinese hotel expansion}

Strategy and timing matching risk

Enterprise internationalization strategy is the company's development plan in the international operation process, is a multinational company in order to put the company's growth into the orderly track, and continuously enhance the competitive power of enterprises and environmental adaptability and the floorboard of a series of decisions.

The location selection risk

Pass in front of the analysis shows that the bilateral development of China's government and the other countries in the world have established strategy, route and plan, and also have their own national 
choose destination travel preference, Chinese hotel in cross-border choosing target countries or regions without joint national policy and national preferences or not will lead to fewer tourists, makes the hotel development prospect. In joint national policy when select the destination point.

The risk of operating mode selection

Foreign economic operation rule, policy environment and specific areas of politics, the rule of law, and many other factors, such as local investment, financing, taxation, accounting, import and export, employment, foreign exchange management, union power and output, consumers' rights and interests, etc., with local vary more or less in our country. [3]Preliminary examination and approval procedures need to be considered municipal planning and the consent of projects around the community residents, business development is very slow, or too much over budget funds invested for the economy, relatively easy to early adopt m\&a mode, heavy assets model is difficult.

Culture compatible challenge

(1) External communication,

Because of the economic, social, cultural, political, legal and customs and habits of conflict and obstacles, the hotel expansion of overseas operations can be difficult to achieve quick profit and success. Nationalism, trade protection, cultural differences and the lack of reliable and stable supplier, could lead to the overseas hotel operations to produce a series of problems: the availability of local resources, the consistency and standards to ensure the quality of product and commitment, can't control the various expenses, etc.

(2) Internal management

In many countries, in order to guarantee the normal operation of the hotel and undisturbed, in addition to the business relationship, flexible and prudent to cultivate social relations and the internal relations must be cultivated. Differences between countries in culture, social customs, values, language, way of working, and there are considerable differences on social behavior, hotel managers are difficult to meet the different needs of guests or staff of different nationalities, and even cause dissatisfaction with guests or staff, complaints, or conflict. Cultural differences and mixed failure is easy to cause the best employees to resign.

\section{Summary}

When our hotel conduct brand cross-border investment, whether it attract the local residents travel is the main consideration. So, in overseas operations for China's tourist hotels, understand the local culture, understand our country residents living and consumption habits, language, understand the management of professional talents is very important. But at present, the hotel management professional higher education in our country appears not long agao, and not in accordance with the above requirement to cultivate graduates. The existing hotel management personnel are mostly came from other sectors.

\section{References}

[1] Chenshun. The international hotel industry overseas market expansion and evolution of regional landscape analysis. Business research, 2016.6: (178-179).

[2] Zhangxiang, ZhangQing. Factors that Affect Hotel multinational enterprise expansion location choice. Economic geography, 2015.3: (185-190).

[3] Kuang Liangbing. Our hotel overseas expansion speed. Modern property, a modern economy, 2015 (14): 18 to 20. 